\title{
A reintegrációs tisztek rendészeti képzésének fejlödési íve
}

\section{FORGÁCS Judit ${ }^{1}$}

\begin{abstract}
A szolgálati beosztásokhoz kapcsolódó képzésnek a szakmai szocializáció több területén kiemelt szerepe van. Az egyén számára ideálisnak mondható képzés alapozza meg leginkább a törvényes szolgálatellátáshoz szükséges szakmai magabiztosságot, kezdeményezőkészséget, kreativitást, felelösségtudatot, az önálló mérlegelési körben való döntést, és támogathatja a szervezeti lojalitás kialakulását és elmélyülését. A reintegrációs tisztek esetében fokozott jelentőséggel bírnak a képzés minőségi mutatói. Dolgozatomban, a jelenlegi rendszer ismertetését megelőzően vizsgálom meg a képzési rendszer elmúlt évtizedeit.
\end{abstract}

Kulcsszavak: reintegrációs tisztek, képzési rendszer, Büntetés-végrehajtási Szervezet, börtön

\section{Bevezetés}

Elöljáróban elmondható, hogy a tisztek állománycsoportjába tartozó nevelők, későbbiekben reintegrációs tisztek² képzése - az alapok elsajátításának időszakában - közösen történt és történik napjainkban is a tiszthelyettesi állománycsoporttal. Csak az alapképzést követő szakirányú specializáció időszakában válik külön, a tanulmányok és a tananyag struktúrája tekintetében. A tisztképzés történetét vizsgálva a nevelők speciális szaktisztképzésének igénye folyamatosan napirenden volt, ennek ellenére a büntetés-végrehajtási felsőoktatás rendszerében az általános tisztképzés keretében történt.

\section{A büntetés-végrehajtási tisztek képzése az 1980-as évekig}

A tisztképzés hőskorában, a speciális (nem rendészeti) diplomát igénylő szakterületek kivételével (orvos, jogász, pedagógus) kizárólag zárt rendszerben, a büntetés-végrehaj-

\footnotetext{
FORGÁCS Judit bv. alezredes, tanársegéd, NKE Rendészettudományi Kar, Büntetés-végrehajtási Tanszék, PhD-hallgató, ME Deák Ferenc Állam- és Jogtudományi Doktori Iskola Judit FORGÁCS correctional Lieut. Colonel, assistant lecturer, University of Public Service Faculty of Law Enforcement Department of Corrections, PhD student, UM Deák Ferenc Doctoral School of Law https://orcid.org/0000-0003-4490-5875; forgacs.judit@uni-nke.hu

2 A 2015. január 1-jén hatályba lépett Bv. törvény a szakma terminológiáját is megújította, és a nevelő kifejezés helyébe az új szemléletmódot tükröző reintegrációs tiszt megnevezés lépett.
} 
tási előmenetel függvénye volt a tisztté válás. A nevelők belső képzése az 1959. június 30-án kiadott 8/1959. BM. sz. utasítás alapján indulhatott meg, amely minden 100 fő fogvatartottra 1 fő nevelői státusz felállítását rendelte el. A szakmai képzés korabeli fellegvárának számító, 1951-ben alapított Büntetés-végrehajtási Központi Kiképző Iskola ${ }^{3}$ csak néhány hónapig adott otthont a nevelők tanfolyami képzésének, amelynek végleges helyszínéül 1959 szeptemberétől a főváros XII. kerületében (volt Rendőrtiszti Főiskola helyén) létrehozott BM Rendőrtiszti Akadémiát jelölték ki. A kétéves nappali és hároméves levelező tagozaton megszerezhető végzettség a tiszti rendfokozat elnyerésén kívül az érettségivel volt egyenértékű, lehetőséget kínált arra is, hogy a végzettek felvételi nélkül megkezdhessék tanulmányaikat a jogtudományi egyetemen. ${ }^{4} \mathrm{Az}$ oktatást az akadémia tanárain kívül a büntetés-végrehajtási szakcsoport két tanára látta el. A büntetés-végrehajtási szakos hallgatók tantervében politikai-világnézeti ismeretek, jogi (büntetőjog, büntető eljárásjog) ismeretek, közismereti (történelem, földrajz, magyar irodalom és nyelvtan) tárgyak, valamint szakmai (szolgálati és őrszolgálati, valamint büntetés-végrehajtási szabályzat, rabnevelés, anyagi és pénzügyi ismeretek) tárgyak szerepeltek, továbbá bőséges óraszámban karhatalmi, harcászati ismeretek. ${ }^{5}$

A fellendülő képzés ellenére 1965-ben az MSZMP Politikai Bizottsága a büntetésvégrehajtás tevékenységéről végzett vizsgálata alapján - többek között - megállapította a tiszti állomány szakmai felkészültségének hiányosságait és hathatós lépéseket sürgetett a valóban megfelelő képzés feltételeinek megteremtésére. „A jelentés következményeként emelték a tisztekkel szembeni felvételi követelményeket, előirányozták a tiszti állomány felsőfokú végzettséghez kötését. A képesítési követelményt előíró 1971. évi 10. sz. törvényerejű rendelet megjelenésének időpontjában a bv. tiszti állományának mindössze 16\%-a rendelkezett felsőfokú végzettséggel.” Annak dacára, hogy kisebb létszámban a szervezet befogadott nem rendészeti diplomával rendelkező munkavállalókat, a felsőfokú végzettséggel rendelkezők aránya jelentős korrekcióra szorult. Még ebben az évben döntés született arról, hogy a büntetés-végrehajtási tiszt képzés betagolódjon a felsőoktatás rendszerébe az 1971-ben alapított Rendőrtiszti Főiskola (RTF) önálló szakaként. A büntetés-végrehajtási felsőfokú graduális képzés 1972-ben két felsőoktatási intézményben indulhatott meg. Az RTF elsősorban a biztonsági és igazgatási szakirányról érkezők képzését vállalta fel, a nevelési szakterület felé orientálódó tiszthelyettesi állomány a szegedi Juhász Gyula Tanárképző Főiskola speciális büntetés-végrehajtási szakirányát választhatta. Említést érdemelnek az 1970-es évek végén indított szaktisztképzések közül a Pénzügyi és Számviteli Főiskolán, valamint a katonai felsőoktatási intézményekben szervezett képzések, ezek

\footnotetext{
X. kerület Maglódi út 125. szám alatti volt egyházi ingatlan, amely parancsnoka neve után „Bakondi Akadémia” néven vált ismertté.

4 Lőrincz József: A büntetés-végrehajtási szakismeretek felsőfokú oktatásának első húsz éve a Rendốrtiszti Főiskolán (1972-1992). Kézirat. 2001. 3.

Uo. 5.

Uo. 2.
} 
azonban sem volumenüket, sem büntetés-végrehajtási specializáltságukat tekintve nem hasonlíthatók az előző két képzési formához.

A korszak kritikájaként elmondható, hogy a gyors beiskolázás, a „diplomagyárak” gőzerejű múködése javított ugyan a tiszti állomány iskolázottsági mutatóin, de ellentmondásosan járult hozzá a valóban hatékony munkavégzéshez. A szaktisztek elhelyezkedését ugyanis az intézetek fogadókészsége és érdeke határozta meg, így alakulhatott ki az a sajátos helyzet, hogy a Juhász Gyula Tanárképző Főiskola elvégzését követően akár biztonsági szakterületen vagy a Rendőrtiszti Főiskola végzett hallgatójaként nevelési szakterületen teljesítettek szolgálatot. Valójában nem a diploma szakmai tartalma, hanem annak megszerzése állt e hallgatólagos zürzavar mögött, ami a tudományos alapú szakmai tartalmak leértékelődéséhez és a gyakorlati tudás mindenhatóságához vezetett. A változás igényét előmozdította az 1979-es kodifikáció ${ }^{7}$ is, amely határozott és korszerűnek mondható jogi környezetet teremtett a büntetés-végrehajtás számára.

\section{A tisztképzés kettős nyomvonala}

Az 1980-as évek szakmapolitikai döntéseinek következménye a mai napig meglévő gyakorlat, hogy a diplomával érkezők és a zárt rendszerű büntetés-végrehajtási képzést elvégzők egyaránt tiszti beosztást tölthetnek be. A tisztképzés kettősségének gyakorlata a magas fluktuációból eredő, hiánypótlást sürgető személyzeti politika eredményeként alakulhatott ki, akadályozva a képzési rendszerünk letisztulását és kikristályosodását. „1972-től 1984-ig a fent említett három főiskolán 370 fő kapott felsőfokú diplomát, ez ugyan rendkívüli erőfeszítések árán történt, de 12 év alatt lényegében elértük, hogy a tisztek csaknem 80\%-ának felsőfokú végzettsége legyen." ${ }^{8}$ A képzés történetének ezen időszakában mulasztottuk el azt a lehetőséget, amely a továbbiakban a nevelők szaktisztképzéséhez is utat nyithatott volna. Megfogalmazódhatott volna az a kérdés, hogy a belső graduális képzést létszámban és minőségben fejlesszük tovább, vagy áttérjünk a posztgraduális képzés rendszerére. Döntéshozókban a természetesnek számító rendészeti mintát követve, talán soha nem merült fel ezen alternatíva lehetősége, így tisztképzésünk napjainkban is kettős nyomvonalon halad.

\subsection{A nem rendészeti diplomával rendelkezök szakmai képzése}

Diplomával az állományba érkező kollégák képzésére is jelentős hatást gyakorolt az országos parancsnok 0130/1979. sz. utasítása, amely a szakmai képzés nélkül nagy számban szolgálatot teljesítők miatti tarthatatlan helyzetre reagált. Az utasítás átfogóan szabályozta a hivatásos állományba kinevezettek képzési rendszerét.

\footnotetext{
1979. évi 11. törvényerejű rendelet a büntetések és az intézkedések végrehajtásáról.

Lőrincz (2001) i. m. 5.
} 
„1980. januártól előírta a kinevezést követő 14 napos kiképzést, amely a legalapvetőbb szolgálati ismeretek elsajátítását volt hivatott biztosítani. Az utasítás az őrszolgálati állomány részére 10 hetes bentlakásos, a többi szolgálati ághoz tartozók részére 12 hónapos levelező rendszerü alapfokú képzést vezetett be." ${ }^{9}$

Az 1980-as évek büntetés-végrehajtási személyzetének anyagi-pénzügyi ellátottsága elmaradt a társszervezetekétől, ezen túl a börtönök túlzsúfoltsága miatt a munkahelyi feltételek romlása a kvalifikált munkaerő, köztük számos pedagógus, pszichológus és gazdasági szakember elvándorlását indította meg. ${ }^{10} \mathrm{~A}$ következő közel tíz év a szakmai képzés színterén nem hozott változást. 1984-től szükségtelenné vált a belső erőből történő intenzív képzés, így a szegedi tanárképzőn és a pénzügyi főiskolán megszűnt az oktatást, ettől kezdve az évi körülbelül 100-120 tiszt utánpótlásának 70\%-át diplomások átképzésével oldotta meg a büntetés-végrehajtási szervezet. Ezzel párhuzamosan kezdődött meg a diplomás új felszerelők 2 éves tanfolyami rendszerű próbaszolgálatos és büntetés-végrehajtási szakvizsgára való felkészítése. ${ }^{11}$

A rendszerváltásig a tisztek szaktanfolyami képzésében jelentős változás nem történt, mivel alapvetően kielégítette a korszakra jellemző szakmai igényeket. Az 1990-es évek első felében erősödtek fel azok a törekvések, amelyek a képzés reformjára irányultak. Az 1976-ban létrejött büntetés-végrehajtási alapfokú iskola (Vác), későbbi nevén Váci Tiszthelyettesképző Iskola, már nem tudott megfelelően alkalmazkodni a változó szakmai igényekhez, mivel az elhelyezési létszám növelésére és az elhelyezési feltételek javítására nem volt lehetőség. A változtatásra való törekvések eredményeként 1996-ban az igazságügy-miniszter 1/1996. (IK.9.) IM határozatával megalapította a büntetés-végrehajtási szervezet személyi állományának alap- és középfokú szakmai oktatására, felsőfokú szaktanfolyami képzésre a Büntetés-végrehajtási Szervezet Oktatási Központját (BvOK). Az intézmény - az akkori igényeknek megfelelő - méltó környezetet, jó személyi és tárgyi feltételrendszert biztosított az oktatómunkához, az európai elvárásoknak mindenben megfelelő törvényes és humánus büntetés-végrehajtást megvalósító személyzet felkészítéséhez. A BvOK 1996-ban meghatározott befogadó képessége 250 fő volt, amely - tekintettel a jelentkező képzési igényekre - már akkor messze alatta maradt a szükséges mértéknek.

A BvOK-ban folytatott, több szakaszra tagolódó képzés első lépcsője az 1980-ban bevezetett, majd 1998-ban minden állománycsoportra kiterjesztett „bevezető képzés"12 volt, amelynek célja a büntetés-végrehajtás állományába kinevezett tisztek (RTF Bv. szakán végzettek kivételével), tiszthelyettesek, valamint a felsőfokú állami iskolai

9 Lipták László: A személyi állomány szakmai képzése és a képzési rendszer korszerüsítésének irányai. Börtönügyi Szemle, 23. (2004), 3. 47-64. 50.

10 Lőrincz József: Visszatekintés a személyi állomány felkészítésének múltjára. Börtönügyi Szemle, 30. (2011), 1. 53-57. 56.

11 Uo. 55.

12 Az 1980-ban bevezetett 14 napos kiképzés időtartama már korábban 15 napra nőtt, elnevezése azonban 1998-ban változott bevezető képzésre. Az új elnevezés egyrészt megegyezik az Európai Tanácsnak a börtönszemélyzet képzésére vonatkozó ajánlásaiban szereplő elnevezéssel (Európai Tanács instrumentuma, Miniszterek Bizottsága 1966. évi 26. sz. határozata és 1997. évi 12. sz. ajánlása), másrészt pontosan és egyértelműen fejezi ki rendeltetését, a képzési rendszerben betöltött funkcióját. 
végzettséghez kötött álláshelyekre kinevezett közalkalmazottak elsődleges felkészítése, a szolgálatba állításhoz elengedhetetlenül szükséges minimális szakmai ismeretek elsajátítása. A képzés időtartama 15 munkanap, 96 óra (ebből 86 óra elméleti és gyakorlati képzés, 10 óra írásbeli és szóbeli vizsga). Ekkor 15 nap képzés és az azt követö sikeres vizsga volt csupán a szolgálatba állitás elöfeltétele!

A 15 napos bevezető képzéssel kapcsolatos kritikák 2001-ig várattak magukra, pedig mindenki számára nyilvánvaló volt, hogy a képzés felépítése, időtartama nem elegendő ahhoz, hogy a dolgozó felelősséggel, megfelelő szakmai színvonalon képes legyen az önálló szolgálatellátásra. Lipták 2004-ben így foglalta össze a bevezető képzés problematikáját: „Az önálló foglalkoztatás komoly szakmai és biztonsági kockázatokat hordoz és a további képesítés mielőbbi megszerzésére sem ösztönöz. Hiányosságként értékelhető az is, hogy a rövid képzési idő alatt a fegyveranyag-ismeret és lókiképzés kivételével nincs szakmai gyakorlati képzés, ezért az alapvető szakmai jártasságokat is a szolgálatellátás közben kell elsajátítani." ${ }^{13}$ A képzési forma hatékonyságát jelentősen csökkentette az is, hogy a nagymértékű fluktuáció miatt gyakran 80-90 fő vett részt egyszerre a tantermi oktatáson. A meglévő helyzetet tovább árnyalta az 1980-as évektől kialakult gyakorlat, amely szerint a képzési intézmény befogadóképességét meghaladó időszakokban képzési decentrumok (kihelyezett képzések) múködtek. A változó mértékű létszámhiány, a „feltöltetlenség” és az állománycserélődés magas aránya jelentősen befolyásolta az induló képzések helyszínét (kihelyezett képzések) és gyakoriságát. A tiszthelyettesi állománnyal való kényszerű együtt mozgás jelentősen rontotta a tiszti állomány felkészülésének hatékonyságát is a bevezető képzés tekintetében.

Az egységes képzés bevezetését követően a felsőfokú végzettséggel állományba vett munkatársaknak az 1 éves próbaidőn belül kellett elvégezniük a felsőfokú szaktanfolyamot, ezt követően kötelezettséget vállaltak a büntetés-végrehajtási szakvizsga letételére. A bevezető képzés 3. hetében kezdődött el a szakvizsgára történő felkészítés, az RTF Bv. Tanszéke tanárainak közremúködésével. A felkészülés alapvetően az önképzésre épült. A képzésben részt vevő saját felkészültségének függvényében maga döntötte el, hogy a rendelkezésére álló 11 hónapon belül, az előre közzétett vizsganapok közül mikor tesz szakvizsgát a BvOK-ban, a Bv. Tanszék szaktanárai előtt.

\section{A képzési rendszer lépcsőzetes reformja}

A képzési rendszer korszerüsítésének igénye 2001-ben vetődött fel komolyabban. A négyhetesre növelt bevezető képzés 2006-os indulását követően két éven belül már látszott, hogy az alapképzés egy héttel megnövelt ideje is kevés. Több éven keresztül zajló egyeztetések, viták, értekezletek eredményeként ${ }^{14} 2008$ elején kezdődött

13 Lipták (2004) i. m. 53.

14 Az előterjesztéseket a BvOP Oktatási Bizottsága, a Parancsnoki Kollégium, végül pedig a büntetés-végrehajtási vezetők, parancsnokok országos értekezlete is több körben megvitatta, kiegészítette, illetve módosította. 
az a tényleges folyamat, amelynek következtében a büntetés-végrehajtási rendszer jelentősen megnövelte az új felvételisek kiképzésére szánt időt. Az elhúzódó döntés hátterében a képzéssel kapcsolatos rossz beidegződések (legyen rövid, hogy minél gyorsabban megtörténjen a szolgálatba állítás) és a képzés belső leértékelődése, jelentős vulgarizálódása (a szakma írott szabályai elolvashatók, de a valós életet jellemző íratlan szabályai csak a gyakorlatban sajátíthatók el) fedezhető fel. Az új rendszerben múködő 14 hetes képzés 2008 szeptemberében - 28 év elteltével - váltotta fel a szakma elméleti oktatásának devalválódásáért felelős három majd négyhetes bevezető képzést. Zakhar így indokolta az új képzési rendszer szükségességét: „A katonai alapismeretek oktatását is magában foglaló alapképzés eredményeként a korábbinál jobban kiképzett, a szolgálati feladatokat színvonalasabban ellátó büntetés-végrehajtási dolgozók kerüljenek ki az iskolából. - Több új tantárgy (informatikai ismeretek, gazdálkodási ismeretek, szolgálati viselkedés lélektana, alaki ismeretek, rendvédelmi közelharc stb.) oktatására nyíljon lehetőség." 15 A képzési rendszer első lépcsős modernizációjából a diplomával érkező leendő nevelők sem maradhattak ki. A számukra előírt 14 hetet követően, próbaidőn belüli szakvizsga-kötelezettségük továbbra is megmaradt.

$\mathrm{Az}$ első lépcsős modernizációt követő képzési rendszer fő tantárgyainak megoszlását tekintve a BvOK fő feladatához illeszkedve (tiszthelyettesi és zászlósi állománycsoport képzése) nem véletlen, hogy a képzés hangsúlyát a biztonsági ismeretek és a gyakorlati oktatás jelentették. ${ }^{16}$ Ebből következik, hogy a polgári diplomával rendelkező leendő nevelők speciális büntetés-végrehajtási képzése számukra teljesen új területekre, a biztonsági ismeretekre és a gyakorlati képzésre koncentrált leginkább. A képzés második szintjét, a büntetés-végrehajtási szakvizsga tananyagrendszerét vizsgálva megállapítható, hogy a biztonsági ismeretek dominanciája kiegészült a jog, a pszichológia és a pedagógia speciális témaköreivel. A szakmai képzésben részt vevő munkatársak már ebben a korai időszakban a biztonsági és jogi tevékenység hegemóniájával találkozhattak, mindeközben megtapasztalták azt a fajta kettősséget, hogy létezik a büntetés-végrehajtásnak egy domináns (biztonsági) és egy szubmisszív (nevelési oldala).

A képzési rendszer korszerüsítésén dolgozó szakembereket újabb kihívás elé állította a 2010-ben megfogalmazott ${ }^{17}$ komplex belügyi-rendészeti oktatás többszintû modernizálását megcélzó program, amely a büntetés-végrehajtás szakképzési, továbbképzési és felsőoktatási rendszerének teljes átalakulását eredményezte. Mindhárom képzési formára jellemző volt, hogy a korábbiaktól eltérő struktúra és vezérlőelvek mentén határozta meg azok működését. Az egy irányba mutató, rendszerközpontú szemlélet bizonyítéka volt az a fajta elvárás, hogy a jövő belügyi oktatása egységes szerkezetben, moduláris rendszerben múködjön, és biztosítsa az átjárhatóságot a különböző rendvédelmi szervek között. Nagy hangsúllyal és kiemelt szerepkörrel bírt a képzés egészét

15 Zakhar Tibor: Gondolatok a megújuló alapképzésről. Börtönügyi Szemle, 30. (2011), 1. 58-62. 60.

16 Forgács Judit: Miért beteg a magyar büntetés-végrehajtási nevelés? Börtönügyi Szemle, 32. (2013), 2. 1-16. 8.

17 Az 5738/2010. számú kormány-elóterjesztésben, illetve a 1282/2010. (XII. 15.) Korm. határozatban meghatározták a rendvédelmi szervek egységes képzési rendszerének új koncepcióját. 
tekintve a gyakorlatorientáltságra való törekvés. Napjainkban kiteljesedő szakmai oktatás modernizációja első lépcsőben a szakképzésünk rendszerét érintette.

A büntetés-végrehajtási szervezet a jogszabályban előírtaknak megfelelően kidolgozta új szakképzési rendszerét, amelynek elfogadását követően újonnan létrehozott büntetés-végrehajtási szakmák létesülhettek. ${ }^{18}$ A Büntetés-végrehajtási Szervezet Oktatási, Továbbképzési és Rehabilitációs Központjában (Oktatási Központ) ${ }^{19}$ 2016-ban megindult büntetés-végrehajtási szakképzés az alapvető törekvéseken túl az informatikai oktatás és az idegen nyelv oktatása mellett a fizikai erőnlét fejlesztését tűzte ki célul. A több modulon keresztül tartó tanulási és munkahelyi szocializációs folyamat rendszere - amely 870 tanóra $^{20}$ teljesítését igényli - az őri minősítéstől a felügyelői szintre vezeti át a frissen felszerelőt.

A nem rendészeti diplomával rendelkezők szakképzése „Rendészeti szervező, büntetés-végrehajtási szervező szakirány” ${ }^{21}$ szakképzés elnevezéssel jelenik meg az Országos Képzési Jegyzékben. A képzés két modulból áll, ${ }^{22}$ amelynek első eleme a „Rendvédelmi alapfeladatok" modul (ez azonos a büntetés-végrehajtási felügyelő szakképzés első moduljával). A 3 hónapot felölelő időszak 350 órás képzése 2 hét intézeti gyakorlatot is magában foglal, amely az állománycsoportok közös képzése során valósul meg. Az alapmodul sikeres teljesítését követi a második már szakmaspecifikus modul a büntetés-végrehajtási szervező szakfeladatainak elsajátítása, amely a korábban említett büntetés-végrehajtási szakvizsgát váltotta fel. ${ }^{23} \mathrm{~A}$ rendészeti szakképzettség megszerzésére kötelezett személy a 2018/19-es tanévtől a képesítési követelményt az NKE RTK rendvédelmi szervező szakirányú továbbképzési szak ${ }^{24}$ elvégzésével is teljesítheti. ${ }^{25}$ A három féléven át tartó hasonlóképpen 360 óra az általános rendészeti ismereteken kívül 116 óra széles körű büntetés-végrehajtási szakmai ismeretet tartalmaz. A képzés szakdolgozattal és komplex vizsgával zárul. A fentiekből is kirajzolódik, hogy képzési rendszerünk fejlődése - a külső diplomával érkezők esetében is - nagy utat bejárva már igen távol került a korábban meglévő gyakorlattól.

\footnotetext{
18 Megjelentetése megtörtént az Országos Képzési Jegyzékben 150/2012. (VII. 6.) Korm. rendelet.

19 Jelenleg müködő Büntetés-végrehajtási Szervezet Oktatási, Továbbképzési és Rehabilitációs Központja 2015. július 1-jén, két intézmény egyesítésével jött létre.

20 Míg a régi rendszerben 448 óra elégséges volt, addig az új rendszer már 870 órás elméleti és gyakorlati képzéshez köti a felügyelői beosztásba történő behelyezést.

${ }^{21}$ OKJ 6286101 azonosító számú, rendészeti szervező szakmairány megjelöléssel (Büntetés-végrehajtási szervező) szakképzés. (Engedélyszám: E-000524/2014/A008; 2016. szeptember 7.)

22 A képzés ideje 5,5 hónap.

23 2020. január 1-jétől helyi alapfokú szakmai képzésben vesznek részt a tiszti beosztásba került felsőfokú végzettséggel rendelkezők.

24 NKE RTK Rendvédelmi szervező szakirányú továbbképzési szak Képzési és Kimeneti Követelmények (KKK).

25 Bevezette a 17/2019. (XI. 29.) BVOP utasítás a büntetés-végrehajtási szakmai oktatás és vizsgáztatás rendszeréről.
} 


\section{A felsőfokú tisztképzés rendszere}

A képzési rendszer letisztulásának legfőbb akadálya a rá jellemző kettősség, a felsőfokú képzés modernizációját csak lassítani volt képes. Az 1980-as évekre jelentősen megnövekedett azok aránya, akik külső diplomával érkeztek rendszerünkbe. Korabeli felvételi adatok szerint 1983-85-tól az utánpótlás egyharmadát belső, kétharmadát külső forrásból pótolta a testület. ${ }^{26} \mathrm{~A}$ változó személyzeti igényeket a Bv. Tanszék átlagosan 23 fő hallgató évenkénti kibocsájtásával ${ }^{27}$ nem volt képes pótolni, ezért évról évre csökkent azok aránya, akik az RTF hallgatói állományából kikerülve tisztként kezdték meg szolgálatukat.

Az RTF büntetés-végrehajtási szak nappali tagozatának tantárgyi struktúrája és óraelosztása számos módosítást követően a 1970-es évek végére stabilizálódott, és változatlanságát a rendszerváltásig megőrizte, amely szorosan követte a jogszabályi környezet által diktált szakmai igényeket is. ${ }^{28} \mathrm{~A}$ nappali tagozat képzésének három éve során a képzésre fordítható összes óraszám 3500 óra volt. Ebből az akkor hatályos tanterv szerint 1500 órát foglalt le a klasszikus büntetés-végrehajtási tantárgyak csoportja (bv. jog, bv. igazgatás, bv. pedagógia és pszichológia, bv. biztonság, bv. gazdálkodás és pénzügyi ismeretek). Már akkor kiemelkedett a jogi ismereteket közlő tantárgyak csoportja, amely összesen 1004 órát ölelt fel. A képzési rendszerben nem elhanyagolható arányban voltak jelen a világnézeti tárgyak és alapozó humán tárgyak (pszichológia, statisztika, vezetési ismeretek). A gyakorlati képzés kiemelt jelentőségét bizonyította a szakmai gyakorlat, a testnevelés, az idegen nyelvi képzés, a gépjármüvezetői jogosítvány megszerzése, illetve a katonai-karhatalmi felkészítésre fordítandó óraszám. ${ }^{29} \mathrm{~A}$ csekély kibocsájtott hallgatói létszám ellenére a szakmai képzés megindulásának 15. évfordulójára (1985) kiadott vizsgálat megállapításai között szerepelt néhány, a hallgatók beválására vonatkozóan. A vizsgált időszakban végzettek 85\%-a a testületnél maradt, és 23\%-a vezetői beosztásban teljesített szolgálatot. Tehát számokkal is bizonyítható, hogy a Tanszék müködésével egy olyan többletet generál, amely megmutatkozik a volt hallgatók pályán maradási hajlandóságban és karrieresélyeiben. A vizsgálat meglepő adatokkal szolgált a szakterületi elhelyezkedésre vonatkozóan, rácáfolt arra a hivatalosan ki nem mondott állításra, miszerint a képzés a biztonsági és igazgatási szakterületet támogatja leginkább: a kibocsátottak többségét, 34\%-át a bv. biztonsági szolgálatához, 20\%-át a nevelési, 12\%-át az igazgatási, 28\%-át anyagi-pénzügyi, míg 6\%-át egyéb szakterületen osztották be. ${ }^{30}$

„A rendszerváltást követően a főiskola más szakaival együtt a bv. szakos képzés tantárgyi struktúrája is jelentősen átformálódott, a fejlesztés »szlogenje« a professzionális

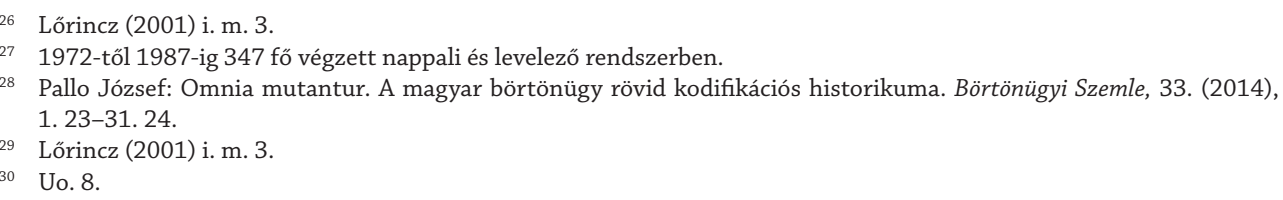


tisztképzés lett."31 (Jelentős volt a világnézeti tárgyak óraszámának csökkenése, ezzel párhuzamosan tovább emelkedett a jogi alapozó tárgyak óraszáma és a professzionális képzés jegyében a szakmai tantárgyakra fordítható órák száma. A tisztképzés elindulásának 20. évfordulóján (1992), a Tanszék által összesített adatok alapján, 399 végzett tisztből minden ötödik, míg a külső diplomával rendelkezők közül minden második hagyta el a pályát. „A főiskolán folyó bv. szakos képzés első húsz esztendejének mérlege egyértelműen pozitív volt, amely nem csupán mennyiségi, de minőségi szempontból is elősegítette a tiszti állomány generációváltását." ${ }^{32}$

Ezt követő időszakban a felsőfokú képzési rendszer tantárgyi struktúráját kétévenkénti finom korrekció jellemezte, de nagyobb átható változtatáson nem ment keresztül. A belső utas tisztképzésünk két pillére a BvOK és az RTF Bv. Tanszéke maradt tartósan. A büntetés-végrehajtási keretek között múködő szaktisztképzés rendszere továbbra sem valósult meg. A specializált nevelőképzés igényére reagálva 2005-ben indulhatott meg elsőként hazánkban a Zrínyi Miklós Nemzetvédelmi Egyetemen a Büntetés-végrehajtási nevelő alapképzési szak külső jelentkezők számára. A szak tudományos múhelye a Szociológia Pszichológia és Pedagógia tanszék volt, azon belül is a pszichológia szakcsoport. Céljaik között szerepelt, hogy hallgatóikat megismertessék a fogvatartottak szociálpszichológiai jellemzőivel, és megfelelő bázist adjanak a szükséges nevelési módszerek kiválasztására; a zárt intézményekben alkalmazható csoportos és egyéni fejlesztési módszerek bevezetésére és alkalmazására. Bár a meghirdetett szakon történő képzés nem volt folyamatos, de kisebb megszakításokkal a Nemzeti Közszolgálati Egyetem létrejöttéig (2012) múködött.

Ezzel párhuzamosan a Bv. Tanszékre felvételt nyert, általános tisztképzésben részt vevő hallgatók a bevezető és alapképzést követően, próbaidejüket letöltve minimálisan egyéves (később kétéves) tiszthelyettesi munkaviszonnyal rendelkeztek, így a büntetés-végrehajtási biztonságban, gyakorlatban alapvető jártasságot szereztek. A tananyagrendszer vizsgálatára 2011-ben került sor, mikor megállapítást nyert, hogy a Tanszékre felvett hallgatók alapvetően a bv. biztonságban és a gyakorlatban jártasak. A képzés három éve során széles körü jogi ismeretek (31\%) elsajátítására volt lehetőség, amelyet tovább erősítettek a biztonsági tantárgyak (17\%) és a főiskolán szerzett gyakorlati tapasztalatok (16\%). A neveléstudományi, pszichológiai és más humán tantárgyak 6-8\%-os arányban voltak jelen a képzésben. ${ }^{33}$ Képzési rendszerünk szaktanfolyami és felsőfokú rendszerére egyaránt igaz állítás, hogy a jogi- és biztonsági tárgyak hegemóniája kendőzetlenül a szakma és az intézetek elvárásait tükrözik, az üzenet egyértelmű: a képzésben végzett tisztek és tiszthelyettesek leginkább a jogi, biztonsági és gyakorlati ismereteikkel tudnak érvényesülni. Ennek következménye, hogy „a humán értékeket közvetítő tantárgyak és az ahhoz kapcsolódó speciális tudás háttérbe szorulnak a valós büntetés-végrehajtási kompetenciakörben" ${ }^{34}$

\footnotetext{
31 Lőrincz (2001) i. m. 8.

32 Uo.

33 Forgács Judit: Merre tart a nevelés? A nevelői profil vizsgálata. Börtönügyi Szemle, 31. (2012), 1. 63-72. 67.

34 Uo. 9.
} 


\subsection{A felsőfokú tisztképzés modernizációja}

Az RTF 40 éves múködését követően 2012. január 1-jén betagolódott a Nemzeti Közszolgálati Egyetembe, annak Rendészettudományi Karaként múködve tovább. A bolognai folyamat részeként a több évtizedes múltra visszatekintő duális képzést a 2013-2014-es tanévtől, felmenő rendszerben egy új, több ciklusú képzés váltotta fel. A régi duális rendszerben a képzés elemei nem épültek egymásra, a kiegészítő képzés kivételével az egyetemi szintű tanulmányoknak nem volt előfeltétele a főiskolai szintű végzettség megszerzése. Az új többciklusú képzési rendszerben (alap-, mester- és doktori képzés) ${ }^{35}$ javult a képzés minősége, s az eddiginél sokkal szerteágazóbb lehetőségek nyíltak meg a hallgatók előtt. A három, egymásra épülő képzési ciklusból álló képzési rendszer kevesebb bemenetet és benn több átmeneti lehetőséget teremtett, ezzel több időt adva a saját képességek felismerésére. Az alapfokozatot (BA) nyújtó első ciklus magas színvonalú szakmai ismereteket nyújt a végzés utáni elhelyezkedéshez, és egyúttal egy megfelelő elméleti alapozást is a tanulmányok mesterképzésben történő néhány éves munkavégzést követő folytatásához, a mesterfokozat (MA) megszerzéséhez. A mesterképzés 4 féléves, és ennek szintén két kimenete van: a szakterületen történő elhelyezkedés, illetve a doktori képzés ( $\mathrm{PhD}$ ), amely a tudományos fokozat megszerzésére készít fel, és e képzési piramis csúcsát jelenti.

A Bv. Tanszék hallgatói nappali és levelező munkarendben hároméves alapképzési, valamint levelező munkarendben kétéves mesterképzési szakon folytatják jelenleg tanulmányaikat. Az új képzési rendszer a büntetés-végrehajtási szakirányon hallgatott tantárgyak mennyiségére és azok rendszerére is jelentős hatást gyakorolt. Az alapképzésen, nappali munkarendben részt vevő hallgatók óraszáma több mint 1200 órával növekedett a hat félév során. A továbbiakban elmondható, hogy a klasszikus büntetésvégrehajtási szakterületeket támogató ismeretek belső aránya is jelentősen változott. Míg a régi rendszerben a joghoz és a biztonsághoz köthető tantárgyak hegemóniája figyelhető meg, úgy az új tantárgyi struktúra a gyakorlati ismeretek terén eredményezett növekedést. E mellett jelentős változást mutat a klasszikusan humán értékekkel bíró tantárgyak terén is, amelyek arányaikat tekintve a duplájára nőttek. Újdonság még, hogy a képzésbe bekapcsolódó hallgatók több száz órányi társ fegyveres szervhez kapcsolódó (rendőri, határrendészeti, katasztrófavédelmi, katonai, nemzetbiztonsági stb.) tudás birtokában szerzik majd meg diplomájukat.

Ebben a rendszerben a hallgatók, oktatók és kutatók sokkal könnyebben utazhatnak és építhetnek nemzetközi kapcsolatokat, vagyis ez a rendszer biztosítja, hogy a közösségi állampolgárok bármelyik tagállamban akadálytalanul továbbtanulhassanak. 
Az új képzési rendszer, természetesen új tárgyak - szám szerint 22 új tárgy - bevezetésével is járt, amellyel párhuzamosan több tárgyat is kivezettek.

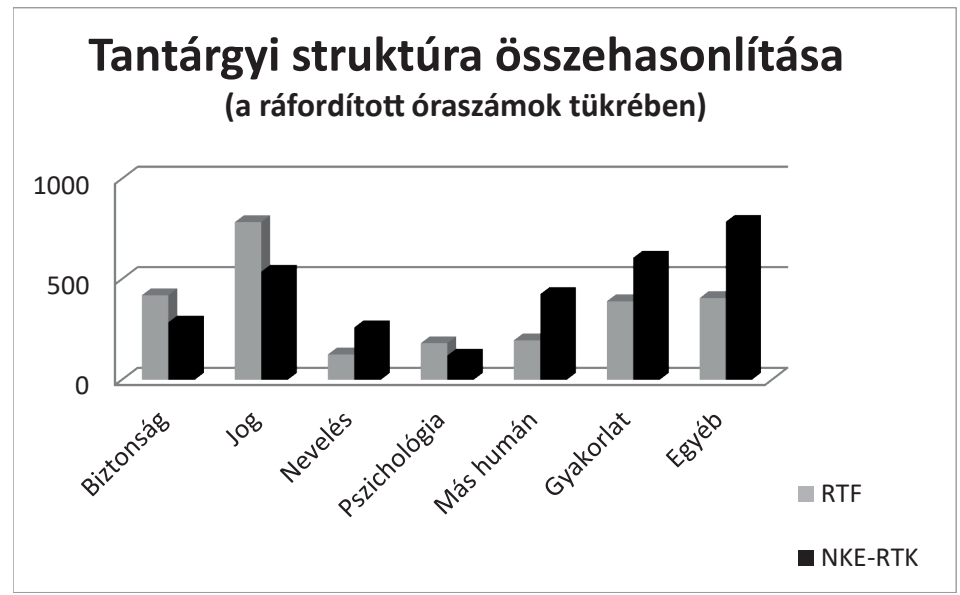

1. ábra: A tantárgyi struktúra összehasonlitása. Forrás: a szerző szerkesztése

A reintegrációs tisztek jellemzőinek 2017-es vizsgálata ${ }^{36}$ következtében újabb eredmények állnak rendelkezésünkre a felsőfokú végzettséghez kapcsolódóan. A vizsgált időszakban az aktív tiszti állomány 16\%-a (362 fö) a Bv. Tanszéken szerezte diplomáját, amely az 1987-es vizsgálat eredményeihez képest a felére csökkent. Míg ugyanez a vizsgálat 20\%-os nevelési szakterületen történő elhelyezkedésrôl ír, jelenleg a reintegrációs tisztek 16\%-a (56 fö) szerezte diplomáját a felsőfokú büntetés-végrehajtási képzésben. Az eredmények tükrében elmondható, hogy a tiszteket, így a reintegrációs tisztek állományát jellemzően a külső diplomával rendelkezők alkotják, ebből következik, hogy képzésükért (szakképzésükért) az Oktatási Központ felel. A reintegrációs szakterületen elhelyezkedő büntetés-végrehajtási szakirányról érkezett hallgatók alacsony arányának okait a képzés tantárgyi rendszerében (jog, biztonság, gyakorlat hegemóniája) és ehhez kapcsolódóan a kezdetektől meglévő biztonsági irányultságú megítélésében kereshetjük.

A Nemzeti Közszolgálati Egyetem Rendészettudományi Kara az Egyetem Fenntartói Testületének határozata alapján 2015 szeptemberében kezdte meg a nappali munkarendes képzés esetében a 4 éves képzésre történő áttérés előkészítését. A Büntetés-végrehajtás Országos Parancsnokságának elvi támogatásával Tanszékünk is bekapcsolódott a négyéves képzés koncepciójának kidolgozásába. Az egyetemi oktatás egyik legfontosabb célja a szakmaspecifikus ismeretanyag átadása annak érdekében, hogy az elsajátított ismeretek biztos alapot teremtsenek a gyakorlatban jelentkező további elvárásoknak való megfelelésre, amelyek a hatályos jogszabályi környezet megfelelő interpretálásával valósulnak meg.

\footnotetext{
36 „A reintegrációs tisztviselők oktatásának, képzésének fejlesztése az eredményes fogvatartotti reintegráció érdekében” című Ludovika Kiemelt Kutatóműhely eredményeit felhasználva. Adatszolgáltatás ideje: 2017. 08. 13.
} 


\section{Következtetések}

A felsőfokú tisztképzés az eltelt 45 év során bizonyította, hogy a folyamatos korszerűsítésre való igény eredményeként létrejött komplex tananyagrendszer kiegészülve a szerteágazó gyakorlati tudnivalókkal, elősegíti a pályaorientációt, erős kötődést alakít ki a büntetés-végrehajtási szakmához. Ennek ellenére a képzés pozitív megítélése nem tűnik elégségesnek ahhoz, hogy az 1980-as években meglévő pozícióját visszaszerezze, az áhított 30\%-os arányt a tisztek képzésében újra teljesítse. A képzéssel szembeni elvárás továbbra is az általános tisztképzés, amely a szaktisztképzést nem támogatja. A jövőre vonatkozóan, a Rendészettudományi Kar a 4 éves képzés rendszeréhez való felzárkózás fejlesztési tervei között azonban már szerepel, hogy az utolsó képzési év lehetőséget nyújtana a két fő terület (biztonság és reintegráció) specializációhoz kötött különválására, ahol már nagyobb sikerrel megvalósulhatna a reintegrációs tisztek mélyebb elméleti, ugyanakkor gyakorlatorientált szakmai ismeretátadása.

A vizsgált időszak fejlődési ívét bemutatva látható, hogy a reintegrációs tisztek (korábban nevelők) szakmai tudása és felkészültsége kulcsfontosságú a napi feladatok végrehajtásában éppúgy, mint a hosszabb távon érvényesülő szervezeti küldetés kiteljesítésében. Igazoltnak látom, hogy ennek jelentőségét mindenkor felismerték a döntéshozók, és ehhez próbálták igazítani a képzések rendszerét. Végső soron hozzájárulva ahhoz a célkitǔzéshez, amely napjainkban így fogalmazódik meg: „A büntetésvégrehajtási jog eszköz- és értékrendszere napjainkban nem uralja, hanem szolgálja az egyént éppúgy, mint a társadalmat." ${ }^{37}$

\section{IRODALOMJEGYZÉK}

Forgács Judit: Merre tart a nevelés? A nevelői profil vizsgálata. Börtönügyi Szemle, 31. (2012), 1. 63-72.

Forgács Judit: Miért beteg a magyar büntetés-végrehajtási nevelés? Börtönügyi Szemle, 32. (2013), 2. 1-16.

Lipták László: A személyi állomány szakmai képzése és a képzési rendszer korszerüsítésének irányai. Börtönügyi Szemle, 23. (2004), 3. 47-64.

Lőrincz József: A büntetés-végrehajtási szakismeretek felsőfokú oktatásának első húsz éve a Rendôrtiszti Föiskolán (1972-1992). Kézirat. 2001.

Lőrincz József: Visszatekintés a személyi állomány felkészítésének múltjára. Börtönügyi Szemle, 30. (2011), 1. 53-57.

NKE RTK Rendvédelmi szervező szakirányú továbbképzési szak Képzési és Kimeneti Követelmények (KKK). Elérhető: https://cmsadmin-pub.uni-nke.hu//document/rtk-uni-nke-hu/rszerv_sztvbk_kepzesi_pr.pdf (A letöltés dátuma: 2020. 01. 21.)

Pallo József: Omnia mutantur. A magyar börtönügy rövid kodifikációs historikuma. Börtönügyi Szemle, 33. (2014), 1. 23-31.

Pallo József: A magyar börtönügy kodifikációs csomópontjai. Budapest, Dialóg Campus, 2019.

Zakhar Tibor: Gondolatok a megújuló alapképzésről. Börtönügyi Szemle, 30. (2011), 1. 58-62.

37 Pallo József: A magyar börtönügy kodifikációs csomópontjai. Budapest, Dialóg Campus, 2019. Ajánló. 


\section{Jogi források}

150/2012. (VII. 6.) Korm. rendelet az Országos Képzési Jegyzékről és az Országos Képzési Jegyzék módosításának eljárásrendjéről

17/2019. (XI. 29.) BVOP utasítás a büntetés-végrehajtási szakmai oktatás és vizsgáztatás rendszeréről

1979. évi 11. törvényerejü rendelet a büntetések és az intézkedések végrehajtásáról 1/1996. (IK. 9.) IM határozat

1282/2010. (XII. 15.) Korm. határozat a rendvédelmi szervek egységes moduláris alapú képzési rendszerének kialakításához szükséges intézkedésekről

\section{ABSTRACT}

\section{The Development Pattern of the Training of Reintegration Officers} Judit FORGÁCS

Trainings related to certain positions and statuses have a key role on the field of professional socialisation. Factors that are indispensable for a lawful conduct (such as professionalism, initiative, creativity, sense of responsibility, and self-reliance in decision-making) are grounded in individually effective trainings which facilitate the establishment (and deepening) of one's loyalty towards a given organisation. The qualitative factors of the training have an increased importance in the case of reintegration officers. In my study, I will examine the last decades of the training system before describing the current system.

Keywords: reintegration officers, training system, Prison Service, prison 